\title{
Teachers' Rooms Environmental Assessment Scale: Development and Psychometric Evaluation
}

\author{
Suna Arslan ${ }^{1}$ \\ ${ }^{1}$ Cumhuriyet University, Faculty of Education, EBB, Sivas, Turkey \\ Correspondence: Suna Arslan, Cumhuriyet University, Faculty of Education, EBB, Sivas, Turkey \\ Received: April 7, 2016 \\ Accepted: April 22, 2016 \\ Online Published: April 24, 2016 \\ doi:10.5430/ijhe.v5n2p292 \\ URL: http://dx.doi.org/10.5430/ijhe.v5n2p292
}

\begin{abstract}
Teachers' rooms are important parts of educational environments, as the quality of the physical-spatial and psychosocial conditions may affect the personal and occupational developments of teachers as well as the education processes. In Study $1(\mathrm{n}=245)$, a Teachers' Rooms-Environmental Assessment Scale (TREAS) measure of the current conditions of teachers' rooms and the determination of the teachers' opinions on such conditions was developed and the initial validity evidence is presented. In Study $2(n=443)$ a confirmatory factor analyses showed support for the scale's two-factor approach. The scale factor conclusions were that the first factor should be labelled 'communication'; the second factor labelled 'physical environment' as sub-scales. The internal consistency reliability was .95. The corrected item-total correlations ranged from .49 to .81 . All studies of the analysis indicated that TREAS was a valid and reliable measurement for the teacher sample.
\end{abstract}

Keywords: Teacher's rooms, Communication environment, Physical-spatial environment

\section{Introduction}

The international labour organizations maintain that occupational environments should comply with the life standards defined as 'well-being of the person for physical, mental and social aspects' (Balkır, 2000; http://www.ilo.org). This principle holds true also for the occupational environments of teachers. It is observed in the Turkish literature that some studies have been conducted on educational environments, and the learning processes, interactive, environmental and behavioural factors of these environments were classified (Alkan 1979; Demirkiran 1995; Yalçınkaya, 2012). The common point of these classifications is that the educational environments address the inter-personal interaction elements and the physical-spatial elements.

Several international organizations investigate the structural features of schools and the working conditions of teachers. CABE, an organization that develops modern school projects (Commission for Architecture and Built Environment), draws attention to the relationship between the quality of education and of environmental design. The criteria of CABE for successful schools in the 'Building Schools for the Future' are architectural identity, settlement, a garden, teaching units and integrality. The Centre for Educational Research and Innovation (CERI) and the Centre for Effective Learning Environments (CELE) can be given as examples of organizations that design innovative educational environments (Dudek, 2000; oecd.org/education; unesco.org/education).

Teacher's rooms are described as the places most commonly used by teachers following their courses, which allows teachers to gather for resting, conversations, meeting, preparing for classes and exchanging information (Clanfeld \& Foord, 2008; Açıkalın, 2014). It is recommended that such rooms should be easy-to-reach and away from noisy areas, placed on each floor in multiple-storey buildings and have adequate communication, equipment, technology and publishing facilities (Kalayc1, 2014). The size of the teachers' rooms in Turkey's educational environment is defined as $16 \mathrm{~m}^{2}$ up to 8 teachers, $24 \mathrm{~m}^{2}$ up to 12 teachers and $1.5 \mathrm{~m}^{2}$ per person over 24 teachers. For such places, the technical features such as an independent instalment system and ventilation, light and heating should be available (egitimmevzuat.com). In the project titled 'Child Friend School,' organized in collaboration with educational and architectural experts, children answered a questionnaire with questions about the physical properties of their dream schools and they included their demands for teachers' rooms (mimarlarodasiankara.org).

It is interesting that there are few studies on the teachers' room in the literature of education science. Karataş (2012) states that the occupational performance of the teacher is associated with the ambience and communication in the teachers rooms. The study focuses on the communicative function of a teachers' room where teachers can interact with each other, as well as the administrators, students and parents. Açikalın (2013) states that the teachers' rooms 
are ignored in school projects, but on the other hand, these units do have some representative clues for the institution, as they are a dimension of the occupational presence, and they are 'private areas', 'a learning environment' and 'a occupational development setting'. Yeşil and Korkmaz (2012), in their study researching the agenda of the teachers' room, determined that teachers speak to each other of the teaching-learning issues 'very often' while they speak of the personal/social/economic and political subjects 'sometimes'. The study of Turhan, Kaptan and Kahveci (2015) about teachers' rooms showed there were educational, actual, personal and professional problems; the teachers' dialogues in the staff room affected some teachers positively, but affected others negatively.

There are also studies indirectly interested in the teachers' room. The School-Level Environment Questionnaire (SLEQ) created by Fisher and Fraser (1991) constitutes articles evaluating the communication aspects of teachers' rooms (Johnson \& Stevens, 2001). Karasolak (2009) states that the architectural and physical-spatial conditions of schools are associated to some extent with each other and recommend cooperation between architectural and educational disciplines. The results of the research by Töremen (2004) relevant to the communication aspect of the teacher's room demonstrate that teachers have personal and group relations regarding this place and have positive/negative perceptions regarding the emotional atmosphere.

Recently, there have been contrary discussions on protection/maintenance of the conventional structure of teachers' rooms or the need for their modification/termination. Clandfield and Foord (2008), in their study investigating the teachers' rooms in six countries, stated that the interpersonal communication that affects the quality of the schools develops in the teachers' rooms. Based on the research, it was stressed that the teachers' rooms have a human environment, physical environment and professional learning environment and suggested that teachers should adopt these rooms and take initiatives. Rossi, Lisahunter et al. (2015) state that teachers' rooms function as 'workplace learning' and they are a 'representative space'. The contrary opinions, on the other hand, advise that schools must not be obliged to allocate a place for teachers, or area/branch teachers' rooms are supported. Besides the views supporting the maintenance of teachers' rooms in education blogs, social and communal areas, some articles argue that such rooms include workplace tyranny risks (Field, 2002, libcom.org/blog; educ-reality.com).

Teaching, considered as an important occupation in all societies, deserves researches on the occupational and psychosocial conditions of teachers and their optimization thereof. Therefore, the problem of the present research was based on developing a scale to use in investigating what/how are the perceptions of teachers on the environmental conditions of teachers' rooms and studies to fill this gap in the field were proposed.

\section{Study 1}

The aim of the study 1 was determine the construct validity of the TREAS with an exploratory factor analysis (EFA).

\subsection{Method}

In this section of the study, the author outlines the item selection procedures of the scale, the study group and the processes regarding the validity assessments. As a result of the document and literature review in accordance with the research problem, it was revealed that the official directive is very narrow in scope and not updated, the number of researches is low, and there is no developed scale in this regard. Qualitative findings were determined by performing content analysis on the observation and interview records obtained by means of making use of the 'unstructured observation' and 'open-ended intense interview' forms developed by the researcher. Upon evaluation of such findings, sample and scale items were developed.

\subsection{Participants and Procedure}

The research included a total of 245 teachers, 118 (47.8\%) were female and 127 (51.4) were male. A working group was randomly created from the primary, secondary and high schools in the province of Sivas from those aged between 24 and 61 . The distribution of teachers by their school levels is $113(46.1 \%)$ from primary schools, 41 (16.7\%) from secondary schools and $91(37.1 \%)$ from high schools. Based on the types of schools, 212 (86.5\%) teachers from public schools, 41 (16.7\%) teachers from private schools participated in the survey. The distribution by branches covers Class Teacher 70 (28.6\%), Mathematics 28 (11.4\%), Turkish Language 18 (7.3\%), Science 16 (6.5\%), Foreign Language 14 (5.7\%), Social Sciences 13 (5.3\%), Gymnastics $12(4.9 \%)$ Literature 11 (4.5\%) and Religion and Morals 9 (3.7\%).

\subsection{The Process of Developing the Items in the Scale}

A pool consisting of 50 items was created as a result of the process of developing the items in the scale. Together with the analysis on the draft items, it was determined that the scale items are qualified to investigate the 'physical/spatial' and 'communicative' aspects and expert opinion was taken after analysing the item contents to title 
the two-factor structure determined by EFA. As a consequence of expert opinions, the first factor was titled as 'communication' while the second factor was titled as 'physical/spatial'. The Teachers' Room-Environmental Assessment Scale (TREAS) draft form was completed by reducing the number of items to 25 and adding a personal details form. General instructions and the instructions for participants to respond based on a 5 -point Likert scale $(1=$ strongly disagree, $5=$ strongly agree) were added to the scale used in this study. The scale was employed on the working group in the 2nd term of the 2014-2015 period, and the implementation period of the scale lasted for two months. The collected data was analysed by the SPSS and AMOS programs.

\subsection{Results and Discussion}

\subsubsection{Exploratory factor analysis}

Prior to performing factor analysis, the Kaiser-Meyer-Olkin (KMO) and the Bartlett's sphericity test were employed to test the sample's suitability for factor analysis. The KMO value for the scale was determined as 0.94 , while the Bartlett's test result was significant $(\chi 2=7019,04 \mathrm{p}<0.001)$. In general, a KMO value above 0.90 for the sample size is considered to be 'excellent' (Tabachnick \& Fidell, 2001). The fact that the KMO value was above the value recommended in the literature, and the fact that the result for the Bartlett's test was significant indicated that the sample satisfied the necessary requirements for factor analysis.

To determine the construct validity of the scale, the following criteria were taken as reference: (1) the eigenvalue of each factor must be at least 1.00; (2) the factor load value of the items loaded to each factor must be positive and have value of at least 0.32 and (3) the value of an item at the factor to which it has been loaded must be at least 0.10 times greater than its value at other factors (Çokluk, Şekercioğlu and Büyüköztürk, 2012). Based on the factor analysis performed with 25 items of the scale, the evaluation of the explained total variance and the common factor variances revealed that there are four factors with eigenvalues greater than 1.00 and noticeable change in the slopes within the scree plot. Based on this reference, the seven items were omitted in the scale. Under evaluation, the scree plot graph showed that breaking takes place in the second factor. The varimax rotation technique was applied by taking into account the obtained data and the structure of the scale and the scale comprises two factors. The total variance explained by these four factors concerning the scale was $57.82 \%$. An evaluation of the variance explained by these two factors showed that the variance contributed by the first and second factors were $45.82 \%, 12 \%$ and eigenvalues of 9.16 and 2.40, respectively. It was observed that first factor loads of the items of the scale varied between .63 and .81 and second factor loads between .83 and .52 . In this context, it was observed that the two factors explained a large portion of the variance regarding the scale. These results provide initial support for the two-factor structure of the TREAS.

\subsubsection{Internal Consistency Reliability}

The Cronbach's alpha internal consistency coefficient was .94. Moreover, the first factor alpha value .93, the second factor alpha value .88 and corrected item-total correlations ranged from .46 to .78 .

\section{Study 2}

The aim of Study 2 was to determine whether TREAS' two-factor structure, as demonstrated in Study 1, would generalize to a different sample. The properties of the TREAS evaluated in the current study include factor structure and internal consistency.

\subsection{Method}

\subsubsection{Participants and procedure}

The distribution of participants by gender in this phase of the research $(\mathrm{N}=445)$ is $216(48.8 \%)$ female teachers and $226(51 \%)$ male teachers. The research group was between the ages of 22 to 64 . According to their schools, teachers of $196(44.2 \%)$ primary schools, $92(20.8 \%)$ secondary schools and $150(33.9 \%)$ high schools participated in the survey. Distribution based on the types of schools is $373(84.2 \%)$ teachers from the public schools, $41(16.7 \%)$ teachers from the private schools. The intensity according to the branches is Class Teacher 131 (29.6\%), English Language 43 (9.7\%), Mathematics 39 (8.8\%), Religion and Morals 22 (5\%), Literature 20 (4.5\%), Turkish Language $20(4.5 \%)$ and Gymnastics 18 (4.1\%), respectively.

\subsubsection{Confirmatory Factor Analysis Results}

The suitability of the CFA results model was first evaluated using the ratio of the chi square value to the degrees of freedom. In this context, the ratio of the chi square to the degrees of freedom must be less than 5 (Çokluk, Şekercioğlu, and Büyüköztürk, 2012). In this study, this ratio was determined as $3.97(524.32 / 132=3.97, \mathrm{p}=.00)$, indicating a good fit. As shown in Table 1, an evaluation of the goodness of fit indices indicated that they varied 
between the GFI $=.90, \mathrm{IFI}=.92, \mathrm{CFI}=.92$ and RMSEA $=.08$ values. According to $\mathrm{Hu}$ and Bentler (1999), Beauducel and Wittmann (2005) and Schreiber, Nora, Stage, Barlow and King, J. (2006), an excellent fit to the data is indicated by GFI, IFI and CFI values 'close to' .95 , (SRMR) value less than or equal to .08 and RMSEA values 'close to' .06. A less ideal but still acceptable fit to the data is indicated by CFI values between .90 and RMSEA values between .06 and .10 (Hu \& Bentler, 1999; Beauducel \& Wittmann, 2009). Based on these references, it was concluded that the two-factor model demonstrated a good level of fit.

Table 1. Summary of Fit Indices of the Teachers' Rooms-Environmental Assessment Scale TREAS

\begin{tabular}{llllllll}
\hline$\chi^{2}$ & Df & $\chi 2 / \mathrm{df}$ & GFI & IFI & CFI & SRMR & RMSEA \\
\hline 524.32 & 132 & 3.97 & .90 & .92 & .92 & .05 & .08 \\
\hline
\end{tabular}

Note: GFI = Goodness-of-Fit index, IFI = incremental fit index, CFI = Comparative fit index, SRMR = Standardized root mean square residual RMSEA = Root mean square error of approximation.

The first factor was labelled 'communication' scales with factor loadings of .71 and .84 respectively. The second factor was labelled 'physical environment' scales, with factor loadings of .55 and .84 . TREAS of the items were significant $(\mathrm{p}<.0 .001)$. In conclusion, the results of the confirmatory factor analysis confirmed the two-factor model of the scale.

Table 2. Teachers' Rooms-Environmental Assessment Scale (TREAS) items and factor loadings obtained from the confirmatory factor analysis of the data of Study $2(n=443)$

\begin{tabular}{lll}
\hline Items & & FL \\
\hline m1 & The place/location of our teachers' room in the school is appropriate & .626 \\
m2 & Size/dimensions of our teachers' room is appropriate/adequate & .701 \\
m3 & Sound/acoustic level of our teachers' room is appropriate & .708 \\
m4 & Heating condition of our teachers' room is appropriate/adequate & .620 \\
m5 & Ventilation/odour conditions of our teachers' room are appropriate & .755 \\
m6 & Light/illumination condition of our teachers' room is appropriate & .662 \\
m7 & Cleanness/maintenance condition of our teachers' room is appropriate/adequate & .711 \\
m8 & Safety/safeguarding condition of our teachers' room is appropriate & .661 \\
m9 & TV, telephone, Internet etc. equipment of our teachers' room is adequate & .552 \\
m10 & Our teachers' room is good for resting and feeling good & .840 \\
m11 & Our teachers' room is good for inter-teacher communication & .808 \\
m12 & Our teachers' room is good for communication with students & .703 \\
m13 & Our teachers' room is good for communication with school administrators/staff & .779 \\
m14 & Our teachers' room is good for having fruitful/quality time & .839 \\
m15 & Our teachers' room is good for rules of good manner/code of conduct & .743 \\
m16 & Our teachers' room is appropriate for teaching occupation and school culture & .813 \\
m17 & Our teachers' room is appropriate for keeping/reading newspaper, journal, etc. & .710 \\
m18 & Our teachers' room is good for having conversation, exchanging ideas & .829 \\
\hline
\end{tabular}

Note: $F L=$ Factor Loading, Communication factor include 11-18 items, Physical environment factor include 1-9 items.

\subsubsection{Internal Reliability}

To determine the internal consistency of the TREAS scores Cronbach alpha was calculated at .95 and corrected item-total correlations ranged from .54 to .82 for the total scale (18 items), which can be considered high. Alpha was .94 and corrected item-total correlations ranged from .49 to .81 for the first factor (communication). Cronbach alpha was .88 and corrected item-total correlations ranged from .49 to .70 for the second factor (physical environment). It is mentioned that items with an item-total correlation of 0.30 or greater are generally good at distinguishing individuals and that they should consequently be included into the scale (Çokluk, Şekercioğlu and Büyüköztürk, 2012). These values support the internal consistency of the TREAS and that the scale's items' values were at an acceptable level. 


\subsubsection{Convergent Validity}

Table 3 shows Pearson $r$ correlations of Social Distance and Teachers' Rooms-Environmental Assessment Scale-subscales. The TREAS and subscale showed positive and significant correlations $(p<.01)$ with social distance. These findings provide support for the TREAS's convergent validity.

Table 3. Correlations among the TREAS and the Social Distance Study $2(\mathrm{n}=445)$

\begin{tabular}{|c|c|c|c|c|}
\hline Variables & 1 & 2 & 3 & 4 \\
\hline 1. Social Distance & & & & \\
\hline 2. Physical Environment & $.217 * *$ & & & \\
\hline 3. Communication & $.381 * *$ & $.593 * *$ & & \\
\hline 4. TREAS & $.343 * *$ & $.864 * *$ & $.918 *$ & \\
\hline
\end{tabular}

\subsubsection{Overall Discussion}

The literature review on the educational environments showed that no academic study has been conducted regarding the teachers' rooms and the variables in this area, and there has been a need for a scale to cure this issue. Based upon the statistical analysis on the 'Teachers' Rooms-Environmental Assessment Scale' (TREAS) developed from the above-mentioned facts, it was determined that the scale includes a two-way perception based on evaluating the 'communicative' features of teachers' rooms and 'the physical-spatial structure' which is over this communication.

The fact that the first factor of TREAS was found to be 'communication' is consistent with the results of studies which indicate that the teaching-learning environments are places of effective communication (Fisher \& Fraser,1991; Johnson \& Stevens,2001; Töremen, 2004) and of studies which investigate the communication-interaction characteristics of teachers' rooms (Karataş, 2012; Yeşil \& Korkmaz, 2012). The fact that the 2nd factor evaluates the 'physical-spatial' conditions of the teachers' rooms is in line with the results of the researches oriented on the educational environments (Dudek, 2000; Karasolak, 2009; Kalayc1 2014). The result of the research by Açıkalın (2013) indicates that both communication and physical-spatial conditions affect the educational activities and supports the 2-factor structure of the TREAS scale.

It was observed during the TREAS implementation processes that response time is accordant with the number of items, the spelling and style features are appropriate and that the functionality was ensured regarding the applications being performed in the teachers' rooms and matching with the experiences of teachers.

It is clear that TREAS contributes to the educational sciences with regards to establishing a basis for the debates on sustaining/protecting the current status of teachers' rooms (Clanfeld \& Foord, 2008; Rosi, Lisahunter et al.) or changing/terminating them (Field, 2002; Paton, 2014; www.mebpersonel.com) and to bring the debates into an academic/scientific environment. Designing the behavioural areas by asking the opinions of the beneficiaries is a principle of labour rights and environmental psychology; this purpose will be realized in studies to be conducted by TREAS. The opinions of teachers and even students and parents shall be collected and relevant amendments according to the modern educational, occupational and personal rights of teachers shall be established.

TREAS is expected to lead in investigating the other variables of teachers' room (ergonomics, technology, food and beverage facilities, resting and school culture/occupational culture) in addition to the communication and physical-spatial factors. Supporting the scale with different samples and qualitative approaches will ensure the accumulation of theoretical knowledge about the teachers' rooms. The ultimate objective of the TREAS development and psychometric evaluation is to allow the teachers to raise their awareness and give them a point of view with regards to teachers' room, their own occupational areas.

\section{References}

Açıkalın, A. (2013). Mesleki gelişim ortamı olarak 'ÖĞRETMENLER ODASI'. Öğretmenler Odası Dergisi, 9, $8-10$.

Alkan, C. (1979). Eğitim ortamları. Ankara: A.Ü. Eğitim Fakültesi Yayınları.

Balkır, Z. G. (2000). Çalışma ve Sosyal Güvenlik Hakları, 'İnsan Hakları' [Human rights]. İstanbul: Yapı Kredi Yayınları, 236-259.

Beauducel, A., \& Wittmann, W. (2005). Simulation study on fit indices in confirmatory factor analysis based on data with slightly distorted simple structure. Sturucture Equation Modeling, 12 (1), 14-75. 
Clandfield, L., Foord, D. (2008). Humanising your staff room-Humanising language teaching. http://www.hltmag.co.uk/aug08/sart05.rtf

Çokluk, Ö., Şekercioğlu, G. \& Büyüköztürk, Ş. (2012). Sosyal bilimler için çok değişkenli SPSS ve LiSREL uygulamalart. [SPSS and LISREL Multivariate applications for social sciences]. Ankara: Pegem A Yayıncilık.

Demirkıran, H. (1995). Eğitim kalitesine uygun öğrenme mekanları tasarımı. 5. Ergonomi Kongresi, Milli Prodüktivite Merkezi Yayınları, No: 570, 413-420. İstanbul.

Dudek, M. (2000). Architecture of schools: The new learning environments, Oxford: Architectural Press.

Field, T. (2002). June 2002. Staffroom bullying. The TES Newspaper

Fisher, D., Fraser, B. J. (1991). Validity and use of school environment instruments. Journal of Classroom Interaction, 26(2), 13-18.

Hu, L. T., Bentler, P. M. (1999). Cut off Criteria for Fit Indexes in Covariance Structure Analysis: Conventional Criteria Versus New Alternatives, Structural Equation Modeling, 6(1), 1-55. http://dx.doi.org/10.1080/10705519909540118

Johnson, B., Stevens, J. J. (2001). Explanatory and confirmatory factor analysis of the school level environment questionnaire (SLEQ). Learning Environments Research, 4, 325-344. http://dx.doi.org/10.1023/A:1014486821714

Kalayc1, N. (2014). 'Eğitim ortamlarını tasarlamak, geleceği tasarlamaktır'. http://www.aljazeera.com.tr

Karasolak, K. (2009). Mimari özellikleri farkl ilköğretim okullarındaki ögrrenci ve ögretmenlerin okullarının bina ve bahçeleri hakkindaki görüsslerinin incelenmesi. [The Investigation of The opinions and Teachers and Students About their Schools Building and Gardens in The Primary Schools That Architectural Features Different.]Yüksek Lisans Tezi, Çukurova Üniversitesi, Sosyal Bilimler Enstitüsü, Adana.

Karataş, İ. H. (2012). Gönüllü öğretmenin öğretmenler odasındaki rolü. Öğretmenler Odası Dergisi, 3, 4-5.

Paton, G. (2014). Schools no longer forced to provide staff rooms or canteens. The Telegraph-Education News. 03 July 2014.

Rossi, T., Lisahunter, Christensen, E., Macdonald, D. (2015). Workplace learning in physical education: Emerging teachers' stories from the staffroom, London: Routledge.

Schreiber, J. B., Nora, A., Stage, F.K., Barlow, E. A. \& King, J. (2006). Reporting structural equation modeling and confirmatory factor analysis results: The Journal of Educational Research, 99(6), 323-337. http://dx.doi.org/10.3200/JOER.99.6.323-338

Tabachnick, B. G., Fidell, L. S. (2001). Using Multivariate Statistics. Boston: Allyn and Bacon.

Töremen, F. (2004). İlköğretim okullarının sahip oldukları sosyal sermaye konusunda öğretmen görüşleri. XIII. Ulusal Eğitim Bilimleri Kurultayı (6-9 Temmuz 2004). İnönü Üniversitesi Eğitim Fakültesi, Malatya.

Turhan, B., Kaptan, A. \& Kahveci, H. (2015). Views of Primary and Secondary school Teachers about Teachers Room. Turkish Studies. http://dx.doi.org/10.7827/TurkishStudies.7794

Yalçınkaya, B. (2012). Eğitim ortamında başarının gizli etkeni. [Secret effect of success in educational environment: Ergonomics]. e-Journal of New World Sciences Academy, 7(2), 785-797.

Yeşil, R., Korkmaz, Ö. (2012). Öğretmenler odasında gündem. [Agenda in the School Staffroom]. Pamukkale Üniversitesi Eğitim Fakültesi Dergisi, 31, 107-122.

Eğitim yapıları mimari proje hazırlanması genel ilkeleri (2010). www.egitimmevzuat.com

https://libcom.org/blog/staff-rooms-place-organise-26022012

http://educ-reality.com/life-in-a-school-staffroom. Teacher education 11012007.

http://www.ilo.org/global/industries-and-sectors/education

https://www.oecd.org/education/education

www.unesco.org/education

www.mimarlarodasiankara.org 